\title{
How to Intervene in the Caries Process: Early Childhood Caries - A Systematic Review
}

\author{
Julian Schmoeckel $^{\mathrm{a}}$ Kristina Gorseta $^{\mathrm{b}}$ Christian H. Splieth $^{\mathrm{a}}$ Hrvoje Juric $^{\mathrm{b}}$ \\ ${ }^{a}$ Department of Preventive and Paediatric Dentistry, University of Greifswald, Greifswald, Germany; ${ }^{\text {b Department of }}$ \\ Paediatric and Preventive Dentistry, School of Dental Medicine, University of Zagreb, Zagreb, Croatia
}

\section{Keywords}

Early childhood caries · Nonoperative · Restoration ·

Treatment $\cdot$ Children $\cdot$ Review

\begin{abstract}
For an Organisation for Caries Research/European Federation of Conservative Dentistry consensus, this systematic review is aimed to assess the question of how to manage the caries process in the case of early childhood caries (ECC). Medline via PubMed was searched systematically regarding management of ECC. First priority was existing systematic reviews or randomized clinical trials otherwise cohort studies dealing with management of ECC, primarily with carious anterior teeth. After data extraction, the potential risk of bias was estimated depending on the study types, and the level of evidence was evaluated. Regarding management of ECC, results are presented for silver diamine fluoride (SDF, $n=5$ ), nonoperative caries management (NOCM, $n=10)$, and restorative approaches (RA, $n=8$ ) separately, as different kinds of studies with different levels of evidence were found for the different aspects in the management of ECC. The 5 systematic reviews on SDF showed a high potential for arrest of ECC on a high level of evidence. In NOCM, a low level of evi-
\end{abstract}

karger@karger.com

(c) 2020 S. Karger AG, Basel

www.karger.com/cre

Karger $\stackrel{2}{*}$ dence for a moderate effect of fluoride varnish in arresting or remineralizing, especially non-cavitated lesions, was assessed. For RA in carious anterior upper primary teeth, a low level of evidence was found for higher failure rates of glass ionomer cement and composite fillings than composite strip crowns even if placed under general anaesthesia and especially compared to other crowns (stainless steel and zirconia). In conclusions, ECC may be managed successfully with nonoperative (SDF, regular fluoride application) and moderately well with operative approaches, but the decision is affected by many other variables such as pulpal involvement, the child's cooperation, or a general anaesthesia setting.

(c) 2020 S. Karger AG, Basel

\section{Introduction}

Early childhood caries (ECC) is a specific form of caries that occurs in children on primary teeth. ECC is worldwide and a highly prevalent disease [Chen et al., 2019] and should be considered a relevant burden for the children and their families [Thomson, 2016]. ECC is characterized as "the early onset of caries in young children with often fast progression which can finally result in complete destruction of the 
primary dentition" [Machiulskiene et al., 2019]. The aetiology of ECC is quite clear: high sugar intake usually via a nursing bottle and insufficient or no oral hygiene, as parents do not brush or not well enough, leading to an atypical pattern of caries attack, particularly on smooth surfaces of upper anterior teeth in young children [Drury et al., 1999; Tinanoff et al., 2019; Wyne, 1999; Machiulskiene et al., 2019]. In contrast to the ECC classification regarding typical clinical patterns [Wyne, 1999], the epidemiological ECC classification of ECC records any carious lesions in primary teeth in children younger than 6 years [AAPD classification]. Many studies indicate that severe ECC can negatively influence the quality of life in preschool children, but fortunately be improved when treated [Collado et al., 2017]. Moreso, due to young age and often low cooperation, general anaesthesia (GA) or sedation is frequently necessary for invasive dental interventions (e.g., fillings, pulp therapy, extraction), going along with higher risks for the children and efforts for families, and also considerable costs for the health systems [Casamassimo et al., 2009; Thomson, 2016]. This leads to a more complex dental decision making in how to manage ECC as not only the diagnosis of the caries lesion at the tooth level but also the caries management on the patient level needs to be considered. Furthermore, dentists face a lot of challenges when planning operative interventions of (severe) ECC:

- The morphology of primary teeth in comparison with permanent teeth is different; as they exhibit large pulp chamber and a thinner enamel-dentin layer, which shorten the time for the caries process to reach the pulp and may cause pain and pulp complications.

- Pain and fear caused by ECC in emergency dental care can compromise future oral health-related quality of life of the child.

- Young children are immature, and usually pre-cooperative (sedation or GA might be needed), and a more complex decision-making process as parents are responsible to take care for their child.

- Premature loss of anterior primary teeth may cause problems with eating/biting, difficulties in speech development, and retarded eruption of permanent incisors.

Another paper in this review consortium for a consensus paper of the European Organisation for Caries Research and the European Federation of Conservative Dentistry deals especially with the management of carious primary molars and different methods of removal of carious tissue and the subsequent restorations. Therefore, this topic is not included in this systematic review. This review focuses on the management of ECC, especially carious primary (upper) anterior teeth.
The aim of this review was to systematically evaluate the current state of knowledge on how to intervene in the caries process in carious primary (upper anterior) teeth in ECC.

\section{Material and Methods}

This systematic review aims to answer the following Participants, Interventions, Comparisons, and Outcomes questions:

How to intervene in the caries process in ECC (especially upper anterior teeth)?:

1. What is the effect of non-invasive management options on ECC?

2. What are the success rates of restorative management options of ECC?

The authors discussed the review protocol a priori. No further external registration was performed as the topic was given to the authors by the joined chairs of the Organisation for Caries Research/European Federation of Conservative Dentistry Consensus Workshop on how to intervene in the caries process.

\section{Search Strategy}

For the comprehensive search strategy, Medline was searched via PubMed for appropriate papers up to and including March 2019. The used search terms and the full search strategy are shown in Figure 1. Titles and abstracts were screened to exclude papers not related to the topic. The remaining full-text articles were screened for eligibility and references hand-searched for additional sources. Publications on humans in English language were included.

The inclusion criteria were (Participants, Interventions, Comparisons, and Outcomes):

- Patients: preschool children, ECC, carious incisors, non-cavitated and cavitated (anterior) primary teeth

- Intervention:

- Nonoperative management of carious lesions in primary (anterior) teeth with silver diamine fluoride (SDF) or any other nonoperative strategies or measures of secondary prevention;

- Restorative management of carious lesions in anterior teeth.

- Control:

- Any other nonoperative strategy (or if available restorative approach $[\mathrm{RA}]$ );

- Any other restorative material.

- Outcome:

- Caries or lesion progression (major failure, when necessity for pulpal therapy);

- Survival of restoration (major failure, when pain/necessity for pulpal therapy).

- Meta-analyses, systematic reviews, and in case of no studies for these high evidence levels also randomized controlled trials (RCTs) and/or cohort studies (prospective and retrospective). The exclusion criteria were:

- Permanent teeth, schoolchildren, adults;

- ECC primary prevention, (vast majority of participants with) caries-free primary teeth at baseline;

- Only caries lesions in primary molars;

- Case presentations, case series;

- No clinical outcomes reported. 
Databases search: Medline

Last search: March 2019

Query definition:

(("therapy"[Subheading] OR "therapy"[All Fields] OR "treatment"[All Fields] OR "therapeutics"[MeSH Terms] OR

"therapeutics"[All Fields]) AND early[All Fields] AND ("Childhood"[Journal] OR "childhood"[All Fields]) AND

("dental caries"[MeSH Terms] OR ("dental"[All Fields] AND "caries"[All Fields]) OR "dental caries"[All Fields] OR

"caries"[All Fields])) AND ("dental caries"[MeSH Terms] OR ("dental"[All Fields] AND "caries"[All Fields]) OR

"dental caries"[All Fields] OR "caries"[All Fields]) AND ("infant"[MeSH Terms] OR "infant" [All Fields] OR

"infants"[All Fields]) AND ("child"[MeSH Terms] OR "child"[All Fields] OR "children"[All Fields])

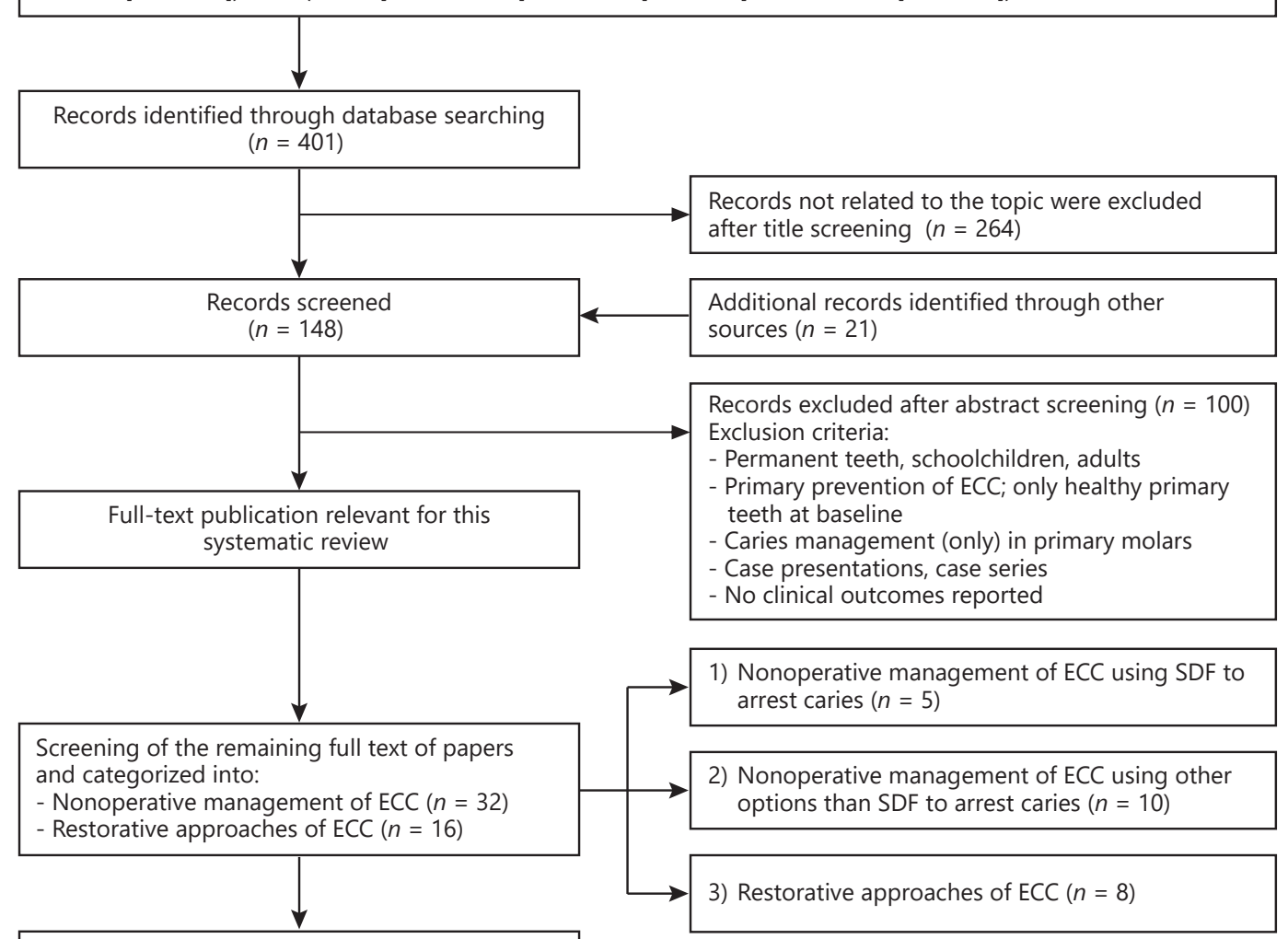

Studies not included $(n=17)$

- For SDF only systematic reviews were included and RCTs excluded $(n=11)$

- Not reporting the information $(n=6)$

- Restorative approaches not related to anterior teeth $(n=8)$

Fig. 1. Flowchart of the systematic review on the management of ECC. ECC, early childhood caries; SDF, silver diamine fluoride; RCT, randomized controlled trial.

\section{Screening, Selection, and Data Extraction}

The title and abstract lists, containing 401 hits, were independently assessed by 2 authors (K.G. and J.S.), respectively. Each of them screened the titles, abstracts, full-texts of eligible papers regarding management of ECC categorized into subchapter (1) nonoperative management (SDF and other nonoperative caries management [NOCM] ) and (2) RAs. Papers with questionable inclusion were discussed in telephone conferences among the authors (K.G., J.S., C.H.S., and H.J.).

Eligible papers were read in full-text by the authors, especially for methodology, bias, and outcome. Disagreement between the authors was resolved by discussion in additional telephone confer- ences. The papers that fulfilled all of the selection criteria were processed for data abstraction (Fig. 1).

Information extracted from the studies included publication details, setting, participants, focused question, search results, comparators, main outcomes, and conclusions (Tables 1-3).

\section{Quality Assessment and Assessment of Heterogeneity}

Depending on the type of studies, the reviewers (K.G. and J.S.) assessed and classified the risk of bias, mostly according to the PRISMA statement for reporting systematic reviews and meta-analyses of studies that evaluate health-care intervention [Liberati et al., 2009] by scoring the reporting and methodolog- 
Table 1. Systematic reviews on nonoperative management of ECC with silver fluoride products

\begin{tabular}{|c|c|c|c|}
\hline Author/year & Study design and sample & Analysis & Main results \\
\hline $\begin{array}{l}\text { Duangthip et al. } \\
\text { [2015] }\end{array}$ & $\begin{array}{l}\text { SR } \\
4 \text { studies ( } 3 \text { RCTs and } 1 \text { cohort), } 3-6 \text { years-old } \\
\text { arresting or slowing down the progression of active dentinal } \\
\text { caries in primary teeth } \\
3 \text { studies: SDF at different application frequencies vs. other } \\
\text { interventions } \\
1 \text { study: SDF versus other interventions }\end{array}$ & $\begin{array}{l}\text { Caries arrested rate } \\
\text { (number needed to } \\
\text { treat) }\end{array}$ & $\begin{array}{l}\text { Three studies reported that topical } \\
\text { applications of SDF solution could } \\
\text { arrest dentinal caries in preschool } \\
\text { children; one study supported that } \\
\text { having a daily toothbrushing exercise in } \\
\text { kindergarten using toothpaste with } \\
1,000 \text { ppm fluoride could stabilize the } \\
\text { caries situation in young children }\end{array}$ \\
\hline $\begin{array}{l}\text { Gao et al. } \\
\text { [2016] }\end{array}$ & $\begin{array}{l}\text { SR and MA } \\
16 \text { trials on primary teeth (SR), }<6 \text { years old } \\
\text { MA ( } 8 \text { RCTs) on } 38 \% \text { SDF to arrest caries in primary teeth } \\
1 \text { study: semiannual SDF applications versus control } \\
1 \text { compared SDF to placebo and sodium FV; } \\
1 \text { study: SDF at different concentrations; } \\
1 \text { study: SDF vs. other interventions; } \\
4 \text { studies: SDF at different application frequencies }\end{array}$ & Caries arrest & $\begin{array}{l}\text { The overall percentage of active carious } \\
\text { lesions that became arrested was } 81 \% \text {; } \\
38 \% \text { SDF was effective in arresting } \\
\text { dentine carious lesions in primary teeth }\end{array}$ \\
\hline $\begin{array}{l}\text { Chibinski et al. } \\
\text { [2017] }\end{array}$ & $\begin{array}{l}\text { SR and MA } \\
11 \text { RCTs, } 4-9 \text { years old } \\
\text { arresting caries in the primary dentition and permanent first } \\
\text { molars } \\
1 \text { study: NSF to placebo } \\
1 \text { study: SDF to placebo } \\
1 \text { study: SDF to no treatment } \\
3 \text { studies compared SDF to ART } \\
2 \text { studies compared SDF to placebo and sodium FV } \\
2 \text { studies compared SDF and sodium FV } \\
1 \text { study compared SDF at different concentrations versus no } \\
\text { treatment }\end{array}$ & Caries arrest & $\begin{array}{l}\text { The use of SDF is } 89 \% \text { more effective in } \\
\text { arresting caries than other management } \\
\text { options or placebos; The quality of the } \\
\text { evidence was graded as high }\end{array}$ \\
\hline
\end{tabular}

SR, systematic review; MA, meta-analysis; RCT, randomized controlled trial; SDF, silver-diamine-fluoride; FV, fluoride varnish; GIC, glass ionomer cement; WMD, weighted mean difference; ART, atraumatic restorative treatment; NSF, nano-silver fluoride; ECC, early childhood caries.

ical quality of the included systematic reviews on NOCM with SDF (online suppl. Table 1; for all online suppl. material, see www.karger.com/doi/10.1159/000504335). A list of 27 items was assessed, and if all individual items were given a positive rating by summing these items an overall score of $100 \%$ was ob- tained. Only systematic reviews including meta-analysis could achieve a full score of $100 \%$. The estimated risk of bias was interpreted as follows: $0-40 \%$ : high risk of bias; $40-60 \%$ : substantial risk of bias; $60-80 \%$ : moderate risk of bias; $80-100 \%$ : low risk of bias. 
Table 2. Overview on the selected studies (part of a meta-analysis, RCTs, cohort studies, partially as cohorts from SDF-RCTs) for NOCM of ECC reporting results on other options than silver fluoride products

\begin{tabular}{|c|c|c|c|c|}
\hline Author/year & Country & Study design and sample & Analysis & Main results/outcome for NOCT \\
\hline $\begin{array}{l}\text { Divaris et al. [2013] } \\
\text { RCT }\end{array}$ & $\begin{array}{l}\text { Australia } \\
\text { aborigines }\end{array}$ & $\begin{array}{l}2 \text { years RCT } \\
n=543 \text { ( } 3-4 \text { years old) } \\
\text { Anterior and posterior teeth } \\
\text { sound and precavitated surfaces } \\
\text { F varnish } 2 \times \text { year } \\
\text { training of primary care coworkers+ } \\
\text { community health promotion }+\mathrm{F} \\
\text { varnish } 2 \times / \text { year } \\
\text { Control group - without treatment } \\
\text { (initial examination and after } 2 \\
\text { years) }\end{array}$ & $\begin{array}{l}\text { Surface level diagnoses } \\
\text { net 2-year surface-level } \\
\text { cavitation risk estimates } \\
\text { (cumulative incidence and } \\
95 \% \text { CL) for sound, } \\
\text { opaque, hypoplastic and } \\
\text { precavitated surfaces at } \\
\text { baseline }\end{array}$ & $\begin{array}{l}\text { The intervention resulted in a } 25 \% \\
\text { reduction (RR } 0.75 ; 95 \% \mathrm{CL}=0.71,0.80 \text { ) } \\
\text { in the } 2 \text {-year surface-level caries risk; } \\
\text { there was substantial heterogeneity in FV } \\
\text { efficacy by baseline surface pathology: } \\
\text { RRs were } 0.73 \text { for sound, } 0.77 \text { for opaque, } \\
0.90 \text { for precavitated, and } 0.92 \text { for } \\
\text { hypoplastic surfaces; Among sound } \\
\text { surfaces, maxillary anterior facials } \\
\text { received significantly more benefit (RR } \\
0.62 \text { ) compared to pits and fissures (RR } \\
0.78 \text { ) }\end{array}$ \\
\hline $\begin{array}{l}\text { Itaborahy et al. [2015] } \\
\text { RCT }\end{array}$ & Brazil & $\begin{array}{l}5 \text { weeks pilot RCT } \\
n=7 \text { ( } 24 \text { active WSL) } \\
2-5 \text { years-old } \\
\text { (1) Duraphat } 1 \times / \text { week for } 4 \text { weeks } \\
\text { (2) Duofluorid XII } 1 \times / \text { week for } 4 \\
\text { weeks }\end{array}$ & $\begin{array}{l}\text { Maximum mesiodistal } \\
\text { and incisogingival } \\
\text { dimensions of WSL } \\
\text { measured with a } \\
\text { periodontal probe; The } \\
\text { average between the } 2 \\
\text { dimensions represented } \\
\text { the value of the WSL } \\
\text { dimension }\end{array}$ & $\begin{array}{l}\text { After } 5 \text { weeks, most WSL were ranked as } \\
\text { inactive }(\mathrm{G} 1=71.4 \% \text { and } \mathrm{G} 2=40 \%) ; \mathrm{n} \\
\text { o significant difference between } \mathrm{G} 1 \text { and } \\
\mathrm{G} 2 \text { in relation to lesion activity was } \\
\text { observed }(p=0.124) \text {; there was a } \\
\text { significant decrease of } 24 \% \text { between } \\
\text { initial }(3.12 \pm 1.49 \mathrm{~mm}) \text { and final WSL } \\
\text { dimension }(2.35 \pm 1.06 \mathrm{~mm} ; p=0.012) \text { in } \\
\text { G1; in G2, there was a significant } \\
\text { reduction of } 40 \% \text { in lesion dimension } \\
\text { with initial value of } 5.7 \mathrm{~mm}( \pm 3.82 \mathrm{~mm}) \\
\text { and final value of } 3.4 \mathrm{~mm}( \pm 3.35 \mathrm{~mm} ; p= \\
0.013)\end{array}$ \\
\hline $\begin{array}{l}\text { Memarpour et al. } \\
\text { [2015] } \\
\text { RCT }\end{array}$ & Iran & $\begin{array}{l}1 \text {-year RCT } \\
n=140 \text { (12-36 months) } \\
\text { anterior maxillary teeth with WSL } \\
\text { (1) control } \\
\text { (2) OH and dietary instr. } \\
\text { (3) OH+FV 4, } 8,12 \text { months after } \\
\text { baseline } \\
\text { (4) OH + tooth mousse } 2 \times / \text { year }\end{array}$ & $\begin{array}{l}\text { Mean percent WSL area } \\
\mathrm{dmft} \text { index values }\end{array}$ & $\begin{array}{l}\text { OH along with } 4 \mathrm{FV} \text { applications during } \\
\text { the } 12 \text {-month period reduced the size of } \\
\text { WSL in anterior primary teeth; } \\
\text { Significant decreases in the size of the } \\
\text { WSL; the greatest reduction was in group } \\
4(63 \%) \text { followed by group } 3(51 \%) \text { and } \\
\text { group } 2(10 \%) \text { after } 12 \text { months. There } \\
\text { were no significant differences between } \\
\text { the groups }\end{array}$ \\
\hline $\begin{array}{l}\text { Duangthip et al. } \\
\text { [2018] } \\
\text { Control cohort } \\
\text { in RCT on SDF }\end{array}$ & Hong Kong & $\begin{array}{l}\text { RCT, } 30 \text { months } \\
n=371(3-4 \text { years }) \\
\text { Gr. (3) } 5 \% \text { NaF } 3 \times / \text { week at baseline }\end{array}$ & $\begin{array}{l}\text { ICDAS scores and caries } \\
\text { arrest }\end{array}$ & $\begin{array}{l}\text { For cavitated lesions (ICDAS code } 5 \text { or } \\
6 \text { ), the caries arrest rate of Group } 3 \text { was } \\
\text { ( } 34 \% \text { ); For moderate caries lesions } \\
\text { without visible dentine (ICDAS code } 3 \text { or } \\
4 \text { ), the caries arrest rates for NaF group } \\
\text { was } 51 \%\end{array}$ \\
\hline
\end{tabular}


Table 2 (continued)

\begin{tabular}{|c|c|c|c|c|}
\hline Author/year & Country & Study design and sample & Analysis & Main results/outcome for NOCT \\
\hline $\begin{array}{l}\text { Chu et al. [2002] } \\
\text { Control cohorts in } \\
\text { RCT on SDF }\end{array}$ & China, RCT & $\begin{array}{l}\text { RCT, } 30 \text { months, } n=375 \text { children } \\
\text { (3-5 years), upper anterior primary } \\
\text { teeth } \\
\text { (3) Excavation }+5 \% \mathrm{NaF} 4 \times / \text { year } \\
\text { (4) } 5 \% \mathrm{NaF} 4 \times / \text { year } \\
\text { (5) Control }\end{array}$ & $\begin{array}{l}\text { Number of arrested caries } \\
\text { lesions }\end{array}$ & $\begin{array}{l}\text { The mean numbers of arrested caries } \\
\text { tooth surfaces in NaF group and control } \\
\text { were } 1.5,1.5 \text {, and } 1.3 \text {, respectively; no } \\
\text { statistically significant differences in the } \\
\text { mean number of arrested carious tooth } \\
\text { surfaces after } 30 \text { months were found } \\
\text { between children who had their caries } \\
\text { excavated prior to NaF varnish } \\
\text { application and those who had not }\end{array}$ \\
\hline
\end{tabular}

\section{Other options for NOCM}

Sitthisettapong et al. Thailand 1 year double-blind, placebo-

[2012]

RCT

controlled clinical trial

$n=150(2.5-3.5$ years old $)$
(1) regular toothbrushing with a

fluoride toothpaste (1,000 ppm)

(CG)

(2) add daily application of $10 \% \mathrm{w} / \mathrm{v}$

CPP-ACP for 1 year

(67.6\% of children had ECC [dmfs of

upper anterior teeth $\geq 1]$, mean

baseline $\mathrm{dmft} 4.3$ )
Transition scores of enamel caries according to ICDAS (regression, stable, or progression)

The odds of enamel caries lesion transitions to a state of regression or stability, compared with progression from baseline, was also not different between groups (OR 1.00, 95\% CI (0.861.17). This trial found that daily application of $10 \% \mathrm{w} / \mathrm{v}$ CPP-ACP paste on school days for 1 year, when added to regular toothbrushing with a fluoride toothpaste (1,000 ppm), had no significant added effect in preventing caries in the primary dentition of these pre-school children

$\mathrm{OH}$ along with constant CPP-ACP during the 12-month period reduced the size of WSL in anterior primary teeth; significant decreases in the size of the WSL; the greatest reduction was in group 4 (63\%) followed by group $3(51 \%)$ and group 2 (10\%) after 12 months; There were no significant differences between the groups

\begin{tabular}{lllll}
\hline $\begin{array}{l}\text { Lo et al. [1998] } \\
\text { CS }\end{array}$ & $\begin{array}{l}\text { Southern } \\
\text { China }\end{array}$ & $\begin{array}{l}\text { 3 years longitudinal study } \\
n=289 \text { children (3-6 years) } \\
\text { (1) regular oral health education and } \\
\text { daily brushing with 1,000 ppm } \\
\text { fluoridated toothpaste } \\
\text { (2) control (no intervention) }\end{array}$ & $\begin{array}{l}\text { Clinical examination } \\
\text { criteria: } \\
\text { arrested caries: dark } \\
\text { brown to black in colour } \\
\text { with hard surface }\end{array}$ & $\begin{array}{l}\text { Statistically significant difference between } \\
\text { the mean no. of arrested caries in Gp 1 } \\
\text { and 2 which was 1.8 and 1.1 respectively; } \\
\text { at 3 years, 28\% of the active dentin caries } \\
\text { in Gp 1 had become arrested while 12\% } \\
\text { of the caries were arrested in the control }\end{array}$ \\
\hline $\begin{array}{llll}\text { Peretz et al. } \\
\text { [2006] CS }\end{array}$ & Israel & $\begin{array}{l}\text { Cohort study, 12 months } \\
n=30(2-4 \text { years) } \\
\text { Lesions on buccal surface }\end{array}$ & $\begin{array}{l}\text { Mean diameter of lesions, } \\
\text { plaque level, brushing and } \\
\text { eating sweets (initial, at } 6\end{array}$ & $\begin{array}{l}\text { The vast majority of patients the } \\
\text { progression of ECC was arrested after a } \\
\text { preventive regimen was implemented }\end{array}$
\end{tabular}

SR, systematic review; MA, meta-analysis; RCT, randomized controlled trial; CS, Cohort study; FV, fluoride varnish; WSL, white spot lesion; ECC, early childhood caries; SDF, silver-diamine fluoride; CG, control group; $\mathrm{OH}$, oral hygiene instructions; NOCM, nonoperative caries management; RR, relative risk.

Only few studies with higher level of evidence reporting outcomes on NOCM and operative options were found, to at least gain some impressions of the results of these various management options not only systematic reviews and RCTs were included. Due to the diversity of the study types, the quality assessment for the nonoperative and operative management of ECC was performed (C.H.S. and J.S.) according to the Newcastle-Ottawa Scale (online suppl. Tables 2,3 ), which is primarily aiming at assessing the quality of nonrandomized studies [Wells et al., 2016].
The heterogeneity across studies was investigated according to the following factors as retrieved by the included literature:

- Study and subject characteristics;

- Methodological heterogeneity (variability in study design and risk of bias);

- Analysis performed (descriptive or meta-analysis). 
Table 3. Studies on restorative approaches regarding management of ECC

\begin{tabular}{|c|c|c|c|c|}
\hline Author/year & Country & Sample and study design & Analysis & Main results \\
\hline Sawant et al. [2017] & India & $\begin{array}{l}1 \text { year randomized clinical study } \\
n=60 \text { ( } 3-5 \text { years old) } \\
\text { evaluation of novel glass fibre-reinforced } \\
\text { composite technique for primary anterior } \\
\text { teeth with deep carious lesions } \\
\text { group I: EverStick glass fibre-reinforced } \\
\text { composite post } \\
\text { group II: ParaPost Taper Lux post }\end{array}$ & $\begin{array}{l}\text { Longevity and failures of posts } \\
\text { in primary maxillary anterior } \\
\text { teeth }\end{array}$ & $\begin{array}{l}\text { After } 3 \text {-month, } 1 / 30 \text { cases in group I } \\
\text { and } 2 / 30 \text { cases in group II showed } \\
\text { failure due to dislodgement of the } \\
\text { posts; at } 6 \text {-month recall, } 3 / 30 \text { cases in } \\
\text { group I and } 11 / 30 \text { cases in group II } \\
\text { showed failure due to dislodgement of } \\
\text { the posts; the difference between the } \\
\text { groups was statistically significant }\end{array}$ \\
\hline Arrow et al. [2016] & Australia & $\begin{array}{l}1 \text { year RCT, } 12 \text { months follow-up } \\
n=254 \text { (mean } 3.8 \text { years), } \\
\text { anterior and posterior teeth ( } 165 \text { anterior } \\
\text { restorations and } 432 \text { posterior } \\
\text { restorations) } \\
\text { (1) ART technique with high viscosity GIC } \\
\text { (2) conventional restoration: local } \\
\text { anaesthetic, rotary instruments, complete } \\
\text { caries removal and restorations (GIC } \\
\text { or resin cements) }\end{array}$ & Restoration retention & $\begin{array}{l}\text { No significant differences in } \\
\text { restorative success between groups } \\
\text { after } 12 \text { months; more children in the } \\
\text { control (49\%) were referred for } \\
\text { specialist care compared with ART } \\
(6 \%) p<0.001 \text {; after } 12 \text { months, } 17 \% \\
\text { of anterior restorations failed } \\
\text { regardless of the group }\end{array}$ \\
\hline Walia et al. [2014] & UAE & $\begin{array}{l}\text { RCT, } 6 \text { months } \\
n=39 \text { children, } 129 \text { anterior teeth } \\
\text { (3-5 years) } \\
\text { (1) Resin composite strip crowns } \\
\text { (2) Preveneered SSCs } \\
\text { (3) Prefabricated primary Zirconiacrowns } \\
\text { placed with behavioural management } \\
\text { techniques and physical restraint }\end{array}$ & $\begin{array}{l}\text { Restoration failure, tooth } \\
\text { wear, gingival health scores }\end{array}$ & $\begin{array}{l}\text { The retention rate was highest for } \\
\text { zirconia crowns (100\%) followed by } \\
\text { preveneered SSCs }(95 \%) \text {; strip crowns } \\
\text { were the least retentive }(78 \%)\end{array}$ \\
\hline Amin et al. [2016] & Canada & $\begin{array}{l}\text { Retrospective cohort study, } 3 \text { years } \\
n=818 \text { children ( } 2-5 \text { years) } \\
\text { Restorative treatments in primary anterior } \\
\text { teeth: } \\
\text { RCRs - anterior buccal/lingual composite; } \\
\text { anterior 2-surface composite; anterior } \\
\text { multi-surface composite; anterior } \\
\text { composite crown } \\
\text { placed under GA }\end{array}$ & Restoration failure & $\begin{array}{l}\text { The success rate of buccal and lingual } \\
\text { anterior RCRs was } 92.4 \% \text {; anterior } \\
\text { 2-surface RCRs had a } 90.2 \% \text { success } \\
\text { over } 3 \text { years; almost half of failed } \\
\text { 2-surface anterior composite } \\
\text { restorations ( } 47.7 \% \text { ) were replaced, } \\
\text { while } 22.7 \% \text {, of them were extracted; } \\
\text { multi-surface anterior RCRs and } \\
\text { anterior resin composite crowns were } \\
\text { successful } 90.9 \text { and } 88.6 \% \text {, respectively }\end{array}$ \\
\hline
\end{tabular}


Table 3 (continued)

\begin{tabular}{|c|c|c|c|c|}
\hline Author/year & Country & Sample and study design & Analysis & Main results \\
\hline Ram et al. [2006] & Israel & $\begin{array}{l}\text { Retrospective study, } 24 \text { months, } \\
n=387 \text { children ( } 2-4 \text { years) } \\
\text { resin-bonded composite strip crowns } \\
\text { placed in primary maxillary incisor }\end{array}$ & $\begin{array}{l}\text { Nr./location of ds, colour, } \\
\text { texture, and chipping of the } \\
\text { restoration; X-ray evaluation: } \\
\text { quality of restoration margins, } \\
\text { presence of pulpal and/or } \\
\text { periapical pathoses, habits }\end{array}$ & $\begin{array}{l}\text { More than } 80 \% \text { of the restorations } \\
\text { were successful at the } 2 \text { years follow- } \\
\text { up; The retention rate is lower in teeth } \\
\text { with decay in } 3 \text { or more surfaces }\end{array}$ \\
\hline
\end{tabular}

SR, systematic review; RCT, randomized controlled trial; SDF, silver diamine fluoride; FV, fluoride varnish; GIC, glassionomer cement; WMD, weighted mean difference; ART, atraumatic restorative treatment; RCR, resin composite restoration; GA, general anaesthesia; SSC, stainless steel crowns; ECC, early childhood caries.

Outcome Measures and Statistical Analysis

Due to the availability of a higher level of evidence for SDF (systematic reviews/meta-analyses) and the fact that in contrast to other NOCM options the effect of SDF was well examined for cavitated carious lesions, this subchapter of NOCM was presented individually (Table 1), whereas other NOCM options are shown together (Table 2). For SDF and other measures of NOCM, the outcome was mainly caries arrest (e.g., hardness, colour, lesion size), and for RA, the main outcome was survival of restoration, that is, restorations not needing any restorative reintervention (replacement or repair).

\section{Results}

\section{Management of ECC}

The results are presented for SDF, NOCM, and RA separately, as different kinds of studies with different levels of evidence were found for the different aspects in managing ECC on the tooth level. No RCT investigated NOCM options versus RA.

\section{Silver Diamine Fluoride}

The application of SDF for ECC has been investigated in many studies. Within the selected manuscripts, there were 5 systematic reviews (Table 1), of which, 3 [Oliveira et al., 2019; Chibinski et al., 2017; Gao et al., 2016] contained a meta-analysis. All of the reviews containing a total of 22 different RCTs which homogenously show the high potential for caries arrest of SDF. The higher the concentration of SDF, the better the arrest rates, espe- cially when applied several times, for example, biannually. SDF solution applied once or twice a year could arrest active caries lesions involving dentine with a success rate of 79 and 91\%, respectively [Duangthip et al., 2015]. Adverse effects such as black stains were reported in studies using 38\% SDF [Duangthip et al., 2015].

\section{Nonoperative Caries Management}

Other NOCM approaches than SDF mostly employed fluoride varnish. For this subchapter, 10 studies were included (Table 2): one systematic review with a part of a meta-analysis [Gao et al., 2016], 5 RCTs, 2 cohort studies, and 2 control cohorts in SDF-RCTs [Duangthip et al., 2018; Chu et al., 2002]. The included studies showed that at least 63.6\% [Gao et al., 2016] up to 81.2\% [Autio-Gold and Courts, 2001] of enamel carious lesions were inactivated after fluoride varnish application. For cavitated lesions, fluoride varnish was effective in $30 \%$ of cases [Duangthip et al., 2018; Lo et al., 1998]. Sodium fluoride varnish has a moderate effect in remineralizing and/or arresting early enamel carious lesions (Table 2) [Gao et al., 2016; Autio-Gold and Courts, 2001; Sitthisettapong et al., 2012; Memarpour et al., 2015], and a lower effect for cavitated carious lesions [Divaris et al., 2013; Duangthip et al., 2018]. Moreso, by brushing with fluoride toothpaste $(1,000 \mathrm{ppm})$, the arrest of ECC may be achieved [Lo et al., 1998; Peretz and Gluck, 2006], but the effect is low with a low level of evidence. There is also limited evidence for efficacy of casein phosphopeptide-amorphous calci- 
um phosphate: Daily application of $10 \%$ casein phosphopeptide-amorphous calcium phosphate paste added to regular toothbrushing with a fluoride toothpaste showed no additional effect in arresting enamel caries in the primary anterior teeth [Sitthisettapong et al., 2012], contrary to the findings of [Memarpour et al., 2015].

\section{Restorative Approaches}

Regarding restorative options in carious anterior upper primary teeth, 8 studies (5 RCTs, 3 cohort studies; Table 3) were included. The level of evidence was assessed as low with a high potential of bias. In many of the studies, restorations were performed under GA (Table 3). Cohort studies showed success rates of composite restorations on tooth level of $50-90 \%$ (81.5\%, 2.5 years [Buecher et al., 2013; Ram and Fuks, 2006]). Looking into more details, multisurface composite restorations had clearly lower retention rates ( $<70 \%$ [Buecher et al., 2013], $80 \%$ [Ram and Fuks, 2006], 90.9\% [Amin et al., 2016]) in anterior teeth than single surface resin composite restorations (>90\% [Buecher et al., 2013; Amin et al., 2016]). Strip crowns had higher success rates $(>80 \%, 2$ years [Ram and Fuks, 2006], 78\% [Walia et al., 2014]) than class III and IV fillings (67.8\% [Buecher et al., 2013]), but lower then preveneered stainless steel and zirconia crowns (95\%, 100\%, respectively $1 / 2$ year [Walia et al., 2014]). Lower retention rates were found for GIC fillings ( $17 \%$ failure, 1 year), regardless if atraumatic restorative treatment or complete removal of carious tissue under local anaesthesia was used [Arrow et al., 2016]. For the use of posts in restoring carious primary maxillary anterior teeth with composite strip crowns, 12 months success rates of $63-98 \%$ were reported [Eshghi et al., 2013; Sawant et al., 2017].

\section{Quality Assessment, Study Outcome Results, and} Assessment of Heterogeneity

The estimated risk of bias regarding systematic reviews on SDF is presented in online supplementary Table 1 , showing moderate to low potential risk of bias and homogenous results.

Due to the diverse types of studies on NOCM (Table 2) and RAs (Table 3), the Newcastle-Ottawa Scale [Wells et al., 2016] was used for quality assessment (online suppl. Table 2,3). Overall, considerable heterogeneity was observed in the NOCM and RAs and materials under analysis, the subject characteristics and outcome measures. Furthermore, quality assessment scales and reporting of effect scores varied among the publications. The results of NOCM were biologically and clinically plausible and mostly in line with each other, as no outlying heterogeneity could be assessed. Nonetheless, a potential for a high risk of bias is present. Regarding operative approaches in ECC, the results were plausible for clinicians and not contradictory, while a potential for a high risk of bias is present due to the study type and underlying confounding factors.

\section{Grading the "Body of Evidence"}

The level of evidence emerging from this systematic review indicates that there is high evidence to support a high effect of SDF in arresting, especially cavitated carious lesions, a low level of evidence for a moderate effect of other NOCM options of ECC, especially non-cavitated lesions, as well as a low level of evidence of moderately high and clinical relevant failure rates for restorative care.

\section{Discussion}

ECC is highly prevalent worldwide and clearly a marker for high caries risks [Chen et al., 2019]. Therefore, it was not surprising that the literature search revealed a large number of studies, but the majority was excluded for this review as they dealt with the epidemiology or the primary prevention of ECC. On the other hand, it was surprising that the management options of ECC have not been investigated profoundly. In addition, rather rare options of posts in primary incisors have been examined in RCTs [Eshghi et al., 2013; Sawant et al., 2017], whereas frequently performed options such as fluoride varnish and fillings (glass ionomer cement, composite) have not been compared with each other in high-quality studies.

Management of cavitated carious lesions in primary teeth of very young children could be performed with SDF, as its effectiveness in arresting the activity of carious lesions (cavitated and non-cavitated) is clearly shown (Table 1). It is easy to apply, even outside dental offices, and relatively inexpensive solutions can be used, especially when compared to restorative intervention under GA. The few but relevant drawbacks of SDF are that: (1) not in all countries a SDF product is available or not to be used for caries management (off-label use only) and (2) the occurring black staining can result in a lower acceptability for caries management by parents/caretakers.

Nonoperative management of ECC has also shown to have moderate potential to inactivate the carious process, especially in enamel lesions (Table 2). The process of inactivation of dentinal carious lesions occurs clearly slower and less predictable, when compared with the applica- 
tion of SDF. Similarly to the findings in this review (Tables 1,2), the American evidence-based clinical practice guideline for NOCM in primary teeth strongly recommends 38\% SDF for any cavitated carious lesion and 5\% sodium fluoride varnish for non-cavitated enamel lesions [Slayton et al., 2018].

The combination of daily toothbrushing with fluoride toothpaste at home and fluoride varnish application in office or kindergartens has the advantageous effect that healthy behaviours such as daily toothbrushing and fluoride use are trained in recall visits, which may influence conviction of parental self-efficacy, laying the responsibility of treatment of ECC into caregivers hands away from the dentist (SDF or restoration). Adherence to oral hygiene instructions and diet counselling are essential in caries management on patient level and should be addressed for long-term effects. Guiding the awareness and understanding of one's responsibility are important for a potential long-term oral health in the children, making it clear that despite other management options NOCM should be obligatory for all children with ECC as an approach of secondary prevention on a child and tooth level.

RAs for the management of ECC are possible, but there was low scientific evidence to suggest that conventional composite fillings for anterior teeth are a valid surgical option in ECC. There is also insufficient information about atraumatic restorative treatment in anterior primary teeth leaving little scientific evidence for the choice of restoration [Waggoner, 2015] or a restoration at all instead of an extraction. Only in the studies where a post was used followed by a composite strip crown, higher success rates could be achieved (Table 3 ).

The RA often masks the caries activity in the child with ECC as the restorations show a high risk of failure frequently due to secondary carious lesions. When taking moderate success rates of $50-90 \%$ on the tooth level even for fillings performed under optimal circumstances such as GA (Table 3), these rates diminish to very low success rates on a patient level due to the usually high numbers of affected teeth in one child. GICs that are less technique sensitive and being placed in only one increment could restore and arrest active dentin carious lesions, but there was low scientific evidence to suggest GIC as material of choice for anterior primary teeth [Zhi et al., 2012]. When a RA is chosen for multisurface cavities, composite strip crowns should be favoured over fillings, but possibly preveneered stainless steel crowns or prefabricated primary zirconia crowns have higher success rates [Walia et al., 2014]. For RAs due to very young age and deep carious lesions with potential pulpal involvement invasive treatment may frequently be performed under sedation or GA with all its risks, efforts and costs, which should always play a role in the individual decision-making process on how to intervene in the carious process of ECC.

\section{Conclusion}

Measures of secondary prevention should always be applied when managing ECC. Additionally, fluoride varnish is to be suggested for non-cavitated lesions and SDF for cavitated dentine lesions without irreversible pulpal involvement, while decisions for RAs should consider patient-related risk factors and the likelihood for the necessity of sedation or GA.

\section{Acknowledgment}

The authors especially thank David Manton for contribution in the search string.

\section{Statement of Ethics}

This research complies with the guidelines for human studies and was conducted ethically in accordance with the World Medical Association Declaration of Helsinki.

\section{Disclosure Statement}

Authors declare no conflicts of interest.

\section{Author Contributions}

J.S., K.G., C.H.S., and H.J. conceived the ideas of the systematic review and the methodological approach; K.G. and J.S. performed the screening and data extraction of this literature review. Final selection was performed by J.S., C.H.S., K.G., and H.J. The writing was led by J.S., C.H.S., and H.J.

References

Amin M, Nouri MR, Hulland S, ElSalhy M, Azarpazhooh A. Success rate of treatments provided for Early Childhood Caries under general anesthesia: A retrospective cohort study. Pediatr Dent. 2016;38(4):317-24.

Arrow P. Restorative outcomes of a minimally invasive restorative approach based on atraumatic restorative treatment to manage Early Childhood Caries: A randomised controlled trial. Caries Res. 2016;50(1):1-8. 
Autio-Gold JT, Courts F. Assessing the effect of fluoride varnish on early enamel carious lesions in the primary dentition. J Am Dent Assoc. 2001 Sep;132(9):1247-53.

Bücher K, Tautz A, Hickel R, Kühnisch J. Longevity of composite restorations in patients with early childhood caries (ECC). Clin Oral Investig. $2014 \mathrm{Apr} ; 18(3): 775-82$.

Casamassimo PS, Thikkurissy S, Edelstein BL, Maiorini E. Beyond the dmft: the human and economic cost of early childhood caries. J Am Dent Assoc. 2009 Jun;140(6):650-7.

Chen KJ, Gao SS, Duangthip D, Lo EC, Chu CH. Early childhood caries and oral health care of Hong Kong preschool children. Clin Cosmet Investig Dent. 2019 Jan;11:27-35.

Chibinski AC, Wambier LM, Feltrin J, Loguercio $\mathrm{AD}$, Wambier DS, Reis A. Silver diamine fluoride has efficacy in controlling caries progression in primary teeth: A systematic review and meta-analysis. Caries Res. 2017;51(5): $527-41$.

Chu CH, Lo EC, Lin HC. Effectiveness of silver diamine fluoride and sodium fluoride varnish in arresting dentin caries in Chinese preschool children. J Dent Res. 2002 Nov;81(11): 767-70.

Collado V, Pichot H, Delfosse C, Eschevins C, Nicolas E, Hennequin M. Impact of early childhood caries and its treatment under general anesthesia on orofacial function and quality of life : A prospective comparative study. Med Oral Patol Oral Cir Bucal. 2017 May;22(3):e333-41.

Contreras V, Toro MJ, Elías-Boneta AR, Encarnación-Burgos A. Effectiveness of silver diamine fluoride in caries prevention and arrest: a systematic literature review. Gen Dent. 2017 May-Jun;65(3):22-9.

Divaris K, Preisser JS, Slade GD. Surface-specific efficacy of fluoride varnish in caries prevention in the primary dentition: results of a community randomized clinical trial. Caries Res. 2013;47(1):78-87.

Drury TF, Horowitz AM, Ismail AI, Maertens MP, Rozier RG, Selwitz RH. Diagnosing and reporting early childhood caries for research purposes. A report of a workshop sponsored by the National Institute of Dental and Craniofacial Research, the Health Resources and Services Administration, and the Health Care Financing Administration. J Public Health Dent. 1999;59(3):192-7.
Duangthip D, Jiang M, Chu CH, Lo EC. Non-surgical treatment of dentin caries in preschool children-systematic review. BMC Oral Health. 2015 Apr;15(1):44.

Duangthip D, Wong MC, Chu CH, Lo EC. Caries arrest by topical fluorides in preschool children: 30-month results. J Dent. 2018 Mar;70: 74-9.

Eshghi A, Kowsari-Isfahan R, Khoroushi M. Evaluation of three restorative techniques for primary anterior teeth with extensive carious lesions: a 1-year clinical study. J Dent Child (Chic). 2013 May-Aug;80(2):80-7.

Gao SS, Zhang S, Mei ML, Lo EC, Chu CH. Caries remineralisation and arresting effect in children by professionally applied fluoride treatment - a systematic review. BMC Oral Health. 2016 Feb;16(1):12.

Gao SS, Zhao IS, Hiraishi N, Duangthip D, Mei ML, Lo EC, et al. Clinical trials of silver diamine fluoride in arresting caries among children: A systematic review. JDR Clin Trans Res. 2016 Oct;1(3):201-10.

Itaborahy R, Machado FC, Elias GP, Ribeiro LC, Ribeiro RA. Clinical effectiveness of two commercial fluoride varnish formulations on the control of white spot lesion in primary teeth: A pilot study. Pesqui Bras Odontopediatria Clin Integr. 2015;15:41-8.

Liberati A, Altman DG, Tetzlaff J, Mulrow C Gøtzsche PC, Ioannidis JP, et al. The PRISMA statement for reporting systematic reviews and meta-analyses of studies that evaluate health care interventions: explanation and elaboration. PLoS Med. 2009 Jul; 6(7): e1000100.

Lo EC, Schwarz E, Wong MC. Arresting dentine caries in Chinese preschool children. Int J Paediatr Dent. 1998 Dec;8(4):253-60.

Machiulskiene V, Campus G, Carvalho JC, Dige I, Ekstrand KR, Jablonski-Momeni A, et al. Terminology of dental caries and dental Caries management: consensus report of a workshop organized by ORCA and Cariology Research Group of IADR. Caries Res. 2019, Epub ahead of print.

Memarpour M, Fakhraei E, Dadaein S, Vossoughi M. Efficacy of fluoride varnish and casein phosphopeptide-amorphous calcium phosphate for remineralization of primary teeth: a randomized clinical trial. Med Princ Pract. 2015;24(3):231-7.

Oliveira BH, Rajendra A, Veitz-Keenan A, Niederman R. The effect of silver diamine fluoride in preventing caries in the primary dentition: A systematic review and meta-analysis. Caries Res. 2019;53(1):24-32.
Peretz B, Gluck G. Early childhood caries (ECC): a preventive-conservative treatment mode during a 12-month period. J Clin Pediatr Dent. 2006;30(3):191-4.

Ram D, Fuks AB. Clinical performance of resinbonded composite strip crowns in primary incisors: a retrospective study. Int J Paediatr Dent. 2006 Jan;16(1):49-54.

Sawant A, Chunawalla Y, Morawala A, S Kanchan $\mathrm{N}$, Jain K, Talathi R. Evaluation of novel glass fiber-reinforced composite technique for primary anterior teeth with deep carious lesions: A 12-month clinical study. Int J Clin Pediatr Dent. 2017 Apr-Jun;10(2):126-30.

Sitthisettapong T, Phantumvanit P, Huebner C, Derouen T. Effect of CPP-ACP paste on dental caries in primary teeth: a randomized trial. J Dent Res. 2012 Sep;91(9):847-52.

Slayton RL, Urquhart O, Araujo MW, Fontana M, Guzmán-Armstrong S, Nascimento MM, et al. Evidence-based clinical practice guideline on nonrestorative treatments for carious lesions: A report from the American Dental Association. J Am Dent Assoc. 2018 Oct; 149(10): 837-49.e19.

Thomson WM. Public Health aspects of paediatric dental treatment under general anaesthetic. Dent J (Basel). 2016;4(2):20.

Tinanoff N, Baez RJ, Diaz Guillory C, Donly KJ, Feldens CA, McGrath C, et al. Early childhood caries epidemiology, aetiology, risk assessment, societal burden, management, education, and policy: global perspective. Int J Paediatr Dent. 2019 May;29(3):238-48.

Trairatvorakul C, Piwat S. Comparative clinical evaluation of slot versus dovetail Class III composite restorations in primary anterior teeth. J Clin Pediatr Dent. 2004;28(2):125-9.

Waggoner WF. Restoring primary anterior teeth: updated for 2014. Pediatr Dent. 2015 MarApr;37(2):163-70.

Walia T, Salami AA, Bashiri R, Hamoodi OM, Rashid F. A randomised controlled trial of three aesthetic full-coronal restorations in primary maxillary teeth. Eur J Paediatr Dent. 2014 Jun;15(2):113-8.

Wyne AH. Early childhood caries: nomenclature and case definition. Community Dent Oral Epidemiol. 1999 Oct;27(5):313-5.

Zhi QH, Lo EC, Lin HC. Randomized clinical trial on effectiveness of silver diamine fluoride and glass ionomer in arresting dentine caries in preschool children. J Dent. 2012 Nov; 40(11):962-7. 